\title{
CONDITIONS OF DEVELOPMENT OF THE AGRICULTURAL BIOGAS INDUSTRY IN POLAND IN THE CONTEXT OF HISTORICAL EXPERIENCES AND CHALLENGES OF THE EUROPEAN GREEN DEAL
}

\author{
WIKTOR IGNACIUK \\ PIOTR SULEWSKI
}

\begin{abstract}
The aim of the study was to assess the current development of the agricultural biogas industry in Poland and to indicate the key factors determining the possibility of popularizing this category of renewable energy in the coming years. The article is based on secondary data. The study uses statistical data on agricultural biogas production from the statistics of Eurostat, the Energy Regulatory Office, and the National Center for Agricultural Support. The S-C-P (Structure-ConductPerformance) analysis was used to synthetically present the collected material and assess the situation of the Polish agricultural biogas industry. The agricultural biogas plants operating in Poland produced only about 325 million $^{3}$ biogas in 2020, from which 689 GWh of electricity was generated. This constitutes a small part of the biogas potential of Polish agriculture (various studies indicate the potential in the range of 1.6-4.2 billion $\mathrm{m}^{3}$ of agricultural biogas from organic fertilizers produced on farms). Electricity obtained from agricultural biogas covers less than $0.4 \%$ of the domestic demand. Despite the ambitious plans created several years ago, the development of the agricultural biogas industry has been practically halted. The main reason for this is great dependence on the system of support with public funds. Further development of the biogas industry requires stable financial support. Despite negative historical experiences, it can be expected that the development of the industry will accelerate in the coming years.
\end{abstract}

\footnotetext{
Wiktor Ignaciuk, MSc, Warsaw University of Life Sciences, Faculty of Economics, Department of Economics and Organization of Enterprises; ul. Nowoursynowska 166, 02-787 Warsaw, Poland (wiktor.ignaciuk@gmail.com). ORCID iD: 0000-0001-6084-4457.

Piotr Sulewski, PhD, DSc, Warsaw University of Life Sciences, Faculty of Economics, Department of Economics and Organization of Enterprises; ul. Nowoursynowska 166, 02-787 Warsaw, Poland (piotr_sulewski@sggw.pl). ORCID iD: 0000-0002-7983-4651.
} 
This is because agricultural biogas has many advantages relevant to the challenges of the European Green Deal. However, there is a need for raising the awareness among policymakers of the environmental and economic benefits resulting from the dissemination of agricultural biogas production.

Keywords: sustainable development, European Green Deal, agricultural biogas, renewable energy sources.

JEL codes: Q42, Q20, Q28, Q40, Q56.

\section{Introduction}

The growing awareness of the impact of human activity on the earth's ecosystem (Rock-ström et al., 2009) and the progressive degradation of the natural environment (World Bank, 2018) stimulate the search for new business models, more focused on decoupling economic growth from the consumption of non-renewable natural resources (UNEP, 2011; Pyka and Prettner, 2018). This postulate expresses the idea of sustainable development. The dissemination of it started an intense debate on the need for changing the socio-economic model that has been functioning (Satterthwaite, 2006). This debate was manifested in, inter alia, events such as the creation of the International Panel on Climate Change (IPCC) (1988), the 1992 Rio de Janeiro Earth Summit, the 1997 Kyoto Protocol, the 2000 Millennium Development Goals Declaration, and the organization of the "Rio+20" conference in 2012 (the so-called second Earth Summit, resulting in the identification of 17 sustainable development goals) (European Parliament, 2012; UN, 2015). Among the directions of searching for management models consistent with the idea of sustainable development, the circular economy concept has been recently emphasized (Birner, 2018; Ellen MacArthur Foundation, 2013; Saavedra, Iritani, Pavan and Ometto, 2018, Savini, 2019; Gołębiewski, 2019) as well as the concept of bioeconomy (Dabbert, Lewandowski, Weiss and Pyka, 2017; Maciejczak, 2015), jointly translating into the postulate of the development of a "circular bioeconomy" (Wąs, Sulewski, and Szymańska, 2019). The beginning of considerations on the circular economy is related to the essay by the American economist Kenneth E. Boulding published in 1966 entitled "The Economics of the Coming Spaceship Earth". The author presented in it a vision of the economy as a system of circulation of raw materials limited by environmental conditions, available resources and the possibilities of waste assimilation (Boulding, 1966). As Saavedra and co-authors (2018) point out, today the concept of circular economy can be perceived as a real option to transform linear and semi-linear material and energy flows into circular flows aimed at increasing sustainability of the system. Circular economy is a production system that aims at increasing the use of renewable energy, eliminating the use of toxic chemicals that make it difficult to re-use and return many products to the biosphere, as well as striving to eliminate waste through better design of products, systems, and business models (Ellen MacArthur Foundation, 2013). Savini (2019) emphasizes that circu- 
lar economy is a model of functioning in which one problem becomes a solution to another, an example of which is the use of biomass waste for biogas production; unnecessary biomass (which is a problematic waste e.g., in food processing) may be used to produce renewable energy (thus contributing to solving the problem of diminishing energy resources and excessive greenhouse gas emissions).

In turn, the concept of bioeconomy refers to those parts of the economy that use renewable biological resources from land and sea to produce food and various types of materials and energy (European Commission, 2012; Fritsche et al., 2020; Birner, 2018; Maciejczak, 2017). According to OECD (2009), bioeconomy can be perceived as an economic system based on advanced knowledge of biotechnology and the use of biomass as a raw material base. Two approaches can be distinguished when defining the concept of bioeconomy: the first is a resource approach and focuses on the use of biomass resources in production processes, while the second emphasizes the use of biotechnology as a method of biomass processing (BÖR, 2010; Birner, 2018; Ratajczak, 2013). Emphasizing the importance of biomass and biotechnology in the context of the challenges of sustainable development leads to the concept of "sustainable bioeconomy, sustainable biobased economy" (Sillanpaa and Ncibi, 2017; Filho, Pociovălișteanu, Brito, and Lima, 2018; Besi and McCormick, 2015). In its assumptions, this concept separates the possibilities of economic development and the necessity to use non-renewable natural resources. In Polish literature on the subject, however, the term "sustainable bioeconomy" can be found (Gołębiewski, 2013). Bioeconomy perceived from this perspective is nowadays becoming a practical dimension of implementing the assumptions of the sustainable development paradigm (Sillanpaa and Ncibi, 2017; Besi and McCormick, 2015; European Commission, 2012; O’Brien, 1999).

The concepts of circular economy and bioeconomy are nowadays important elements of the European Green Deal development strategy promoted in the European Union. It is to be a response to the growing climate crisis (European Commission, 2019a). The key assumption of this strategy is to achieve climate neutrality by 2050 and to decouple economic growth from the consumption of non-renewable environmental resources. The implementation of the assumptions is to be possible thanks to a more efficient use of resources resulting from the transition to a clean circular economy, preventing the loss of biodiversity and reducing the level of pollution. Achieving the objectives of the European Green Deal will require, inter alia, investments in environmentally friendly technologies, introducing cleaner and cheaper forms of transport and reducing the emissions of the energy sector (European Commission, 2019a). At an operational level, such activities will be supported by several initiatives such as "Clean Energy", "Sustainable Agriculture", "Eliminate Pollution", and "Climate Action". The implementation of the strategies is intended to make the EU a modern, resource-efficient, and competitive economy capable of sustainable development.

Considering that more than $75 \%$ of greenhouse gas emissions in the EU come from the generation and use of energy (European Commission, 2019b), it can be 
assumed that energy transformation is the key challenge related to the implementation of the European Green Deal. According to data from 2019, on average, only $18.8 \%$ of the energy consumed in the EU-28 came from renewable sources, and in Poland this indicator was at the level of 12.2\% (Eurostat, 2021). In September 2020, the European Commission proposed to reduce the level of GHG emissions by $55 \%$, as compared to 1990 . It means the need for an intensive search for and implementing solutions conducive to the implementation of this assumption.

In this context, a question can be asked about the role of the agricultural sector in the EU energy transformation, as had been discussed even before the formal development of the "European Green Deal" (Pedroli and Langeveld, 2011; Sulewski, Majewski, and Wąs, 2017). Thanks to production based on biomass, agriculture has a particularly large potential in the field of renewable energy production (Pedroli and Langeveld, 2011). The use of agricultural biomass for energy generation, liquid and gaseous fuels can be considered one of the most promising directions for the development of renewable energy sources (RES) (Gradziuk, 2015; Kisiel, 2006).

The need for increasing the role of agriculture in energy production also results from the share of this sector in greenhouse gas emissions, estimated at $10.3 \%$ in the EU (EEA, 2020), and at about 8\% in Poland (Ministry of Climate, 2020). Nearly half of all greenhouse gas emissions from agriculture directly results from livestock farming. Methane and nitrous oxide are the main greenhouse gases emitted by agriculture. They have an impact on the greenhouse effect of 21 and 310 times greater than that of carbon dioxide, respectively (IPCC, 2006).

A particular importance in the process of increasing the significance of agriculture in the production of renewable energy is assigned to agricultural biogas (Majewski, Sulewski, and Wąs, 2016; Mirosz, Amrozy, Trząski, and Wiszniewska, 2015). Even though Poland has one of the largest potentials in the production of biogas and biomethane in Europe, so far, the production possibilities resulting from the availability of substrates have been used to a small extent (Dach et al., 2020; Gołębiewski et al., 2020; Majewski et al., 2016). In this context, it is worth paying attention to the "Just Transition Mechanism" developed in the EU (aimed at facilitating the implementation of the European Green Deal assumptions). It envisages supporting Poland with the amount of EUR 3.5 billion to implement measures accelerating the decarbonization of the economy. Such activities are to include, inter alia, investments in the development of circular economy and investments in the implementation of technologies and infrastructure concerning cleaner energy, reduction of greenhouse gas emissions, energy efficiency and renewable energy (Woźniakowski, 2020). This process is also to be strengthened by a strategy aimed at reducing methane emissions and an action plan for circular economy (Woźniakowski, 2020). Therefore, the above-mentioned initiatives can also be seen as an opportunity to increase the use of agricultural biogas in energy production. Achieving such a goal, however, requires, inter alia, identifying the reasons for the slow development of the agricultural biogas industry in Poland in the last dozen or so years. 
In this context, the aim of the study was to assess the current development of the agricultural biogas industry in Poland and to indicate the key factors determining the possibility of popularizing this RES category in the coming years.

\section{Materials and methods}

The article is a review and is based on secondary data. The study uses statistical data on agricultural biogas production from the statistics of Eurostat, the Energy Regulatory Office, and the National Center for Agricultural Support. The S-C-P (Structure-Conduct-Performance) analysis was used to synthetically present the collected material and assess the situation of the Polish agricultural biogas industry.

\section{Agricultural biogas as a source of renewable energy}

Agricultural biogas produced from organic fertilizers (manure, slurry) allows not only to replace a certain amount of energy from fossil fuels with renewable energy, but also reduces methane emissions that occur during traditional storage of manure and slurry (Shih, Burtraw, Palmer and Siikamäki, 2012; IPCC, 2006). It is assumed that any reduction of $\mathrm{CO} 2$ emissions by $1 \mathrm{~kg}$ as a result of replacing fossil fuels with agricultural biogas produced from organic fertilizers translates into an additional reduction of emissions by $1 \mathrm{~kg}$ of $\mathrm{CO} 2$ because of changing the fertilizer management system (Mirosz et al., 2016). It is also worth emphasizing that the digestate obtained in the process of producing agricultural biogas is a valuable fertilizer with a less harmful impact on the environment than slurry or manure. Nitrogen in the digestate is in the ammonium form, it is better absorbed by plants and does not contaminate surface waters (Kowalczyk-Juśko and Szymańska, 2015). The use of digestate pulp as a fertilizer reduces the risk of eutrophication processes and helps to maintain an appropriate level of organic matter in soil (Obrycka, 2014).

In the analysis of the usefulness of agricultural biogas, it is worth noting that the efficiency of energy generation in biogas plants differs depending on the method of biogas management. For example, for combined heat and power (CHP) production, the typical electrical and thermal efficiencies are 40 and $50 \%$, respectively. In turn, to produce heat energy by burning biogas in a gas boiler, this value is $82.5 \%$ (Hakawati, Smyth, Mccullough, Rosa, and Rooney, 2017). When compared to other renewable energy sources, biogas plants are characterized by greater production stability (Stejskal, 2008), and biogas itself can be used as an alternative to natural gas in the form of biomethane, e.g., for powering motor vehicles (Majewski et al., 2016; Pomykała and Łyko, 2013). Even though the law in force in Poland allows for the injection of biomethane into the gas network (Journal of Laws 2015, item 478), in practice biogas producers interested in this direction of activity face several formal and legal barriers (Tarka and Trupkiewicz, 2017). A more detailed discussion of the benefits of using agricultural biogas can be found, among others in a study by Pawlak (2013).

When discussing the advantages of agricultural biogas it should be also mentioned that the production of this fuel supports the distributed energy model. 
The model consists in the production of electricity, heat, and liquid fuels on a small scale, in a decentralized manner and focused on local use (Wiśniewski et al., 2012). From this point of view, micro biogas plants (formally up to $40 \mathrm{~kW}$ ) are of particular interest. They can be established even on relatively small farms and used by farmers for their own needs (energy self-sufficiency). Such facilities are usually only powered by biomass from a given farm (group of farms). It eliminates the need for transporting substrates and makes the farms independent from fluctuations in substrate prices (Dobbelaere et al., 2015; Petersen et al., 2016). According to the calculations of Sulewski and co-authors (2016), the required number of livestock for a $40-\mathrm{kW}$ micro biogas plant is 116 DJP, with an assumed consumption of 450 tons of maize silage per year as a co-substrate. In many countries, the creation of agricultural micro biogas plants is linked with less formal requirements than in the case of larger installations (Mirosz et al., 2016; Patersen et al., 2016). One of the key disadvantages of small biogas plants, however, is no economies of scale, achievable with larger plants (Bruins and Sanders, 2012).

\section{Development of the biogas market in Poland so far}

\section{Production level}

The beginning of the development of the agricultural biogas industry in Poland dates to 2005 and the amendments to the Energy Law and Environmental Protection Law that were carried out at that time. The amendment introduced public support systems dedicated to renewable energy sources, being an implementation of EU law into the legal system (Directive 2001/77/EC). In 2005, the first agricultural biogas plant in Poland was also constructed - a 0.94-MW plant by Poldanor (today Goodvalley SA) located in Pawłówko, near a pig farm owned by the company (Igliński, Piechota, Iwański, Skarzatek and Pilarski, 2020). In 2020, 99 entities operated in Poland, they owned a total of 116 biogas installations (Fig. 1) (KOWR, 2020). In the last 10 years, both the number of installations and the number of producers have increased significantly. However, the upward trend has clearly been halted since 2017. A similar pattern of changes can also be indicated in the rate of increase in biogas production; from 2012-2016 it amounted to an annual average of 42 million $\mathrm{m}^{3}$, while from 20172020 this value decreased to 18.8 million $\mathrm{m}^{3}$ (Fig. 2).

In 2020, the existing biogas plants produced only about 325 million $\mathrm{m}^{3}$ of agricultural biogas, used to produce $689 \mathrm{GWh}$ of electricity (Fig. 2). This means that only a small part of the domestic production potential is used. Analyzes by Majewski and co-authors (2016) show that, depending on the adopted technological parameters, the theoretical yield of agricultural biogas production from animal manure alone can be estimated at the level of 1.6 to 4.2 billion $\mathrm{m}^{3}$.

On the other hand, according to Dach, Janczak, and Czekała (2018), theoretical annual biogas yield from animal manure with the addition of other waste substrates (cereal straw, rape, corn straw, waste plant biomass from protected areas, waste from food processing and out-of-date and spoiled food) it may even amount to 13.5 billion $\mathrm{m}^{3}$. It would enable the production of $30 \mathrm{TWh}$ of electricity per year. 
Meanwhile, electricity generated from agricultural biogas made it possible to cover only $0.37 \%$ of domestic electricity consumption in 2019 .

In the context of the observed pace of development, it is worth noting that approximately 2,000 agricultural biogas plants (with a capacity of up to approx. $250 \mathrm{kWe}$ ) were to be constructed in Poland by 2020 pursuant to the plan "Directions for the development of agricultural biogas plants for 2010-2020" adopted in 2010 (Curkowski, Oniszk-Popławska, Mroczkowski, Zowsik, and Wiśniewski, 2011). Currently, the structure of biogas plants is dominated by quite large entities with an installed electrical capacity of more than $0.5 \mathrm{MW}$ (Fig. 3), which indicates that the concept of agricultural biogas plants has not become popular so far.

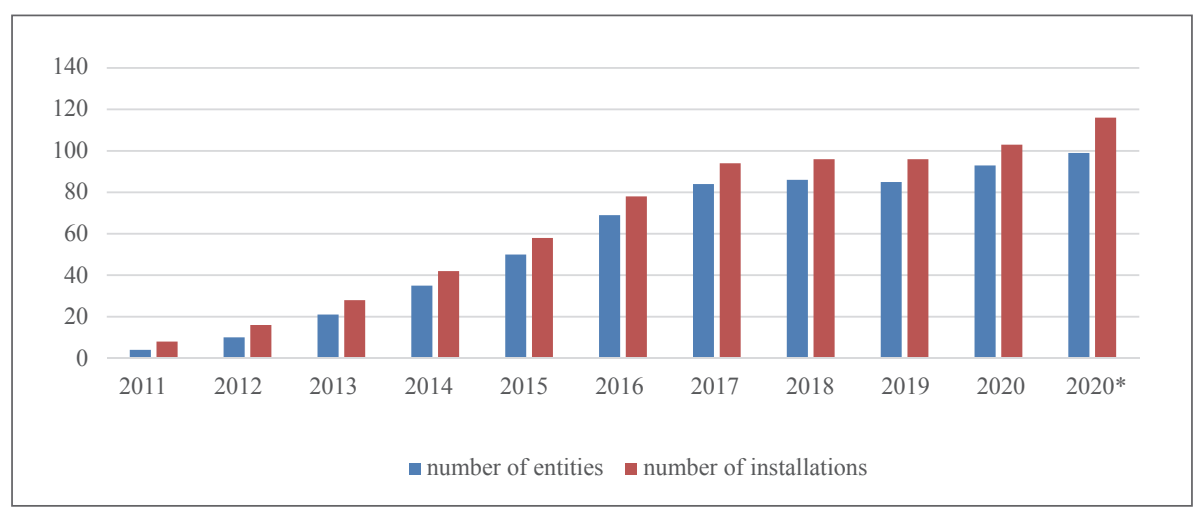

* data valid as of December 31, 2020.

Fig. 1. Number of entities and installations entered in the register of agricultural biogas producers from 2011-2020.

Source: National Center..., 2020.

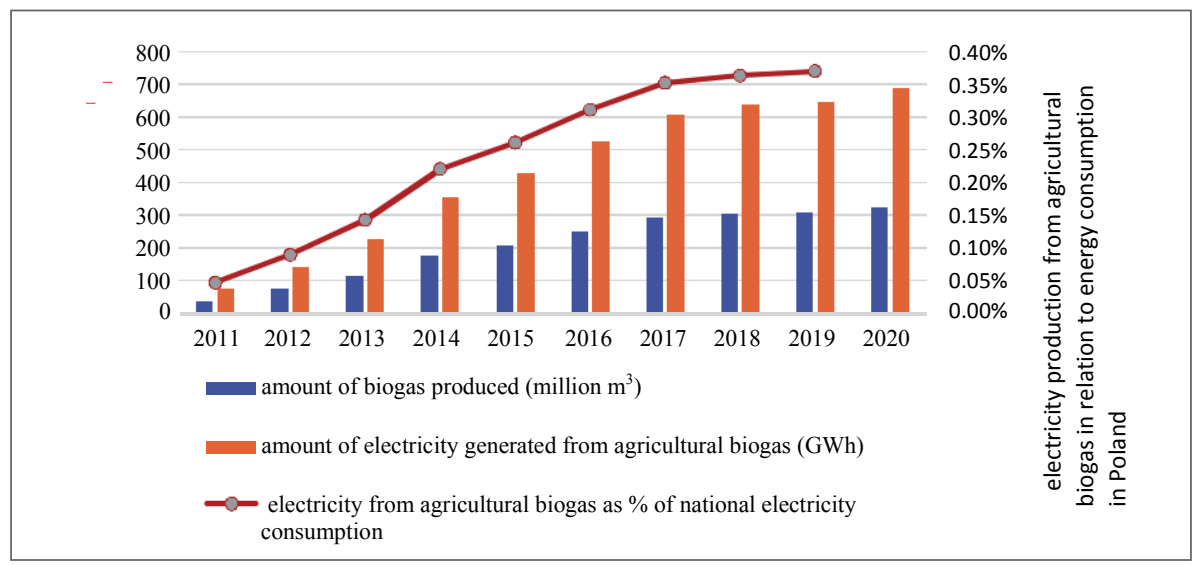

Fig. 2. Production of agricultural biogas and electricity from agricultural biogas from 2011-2020. Source: calculations based on the data of the National Center for Agricultural Support and Statistics Poland (2021). 


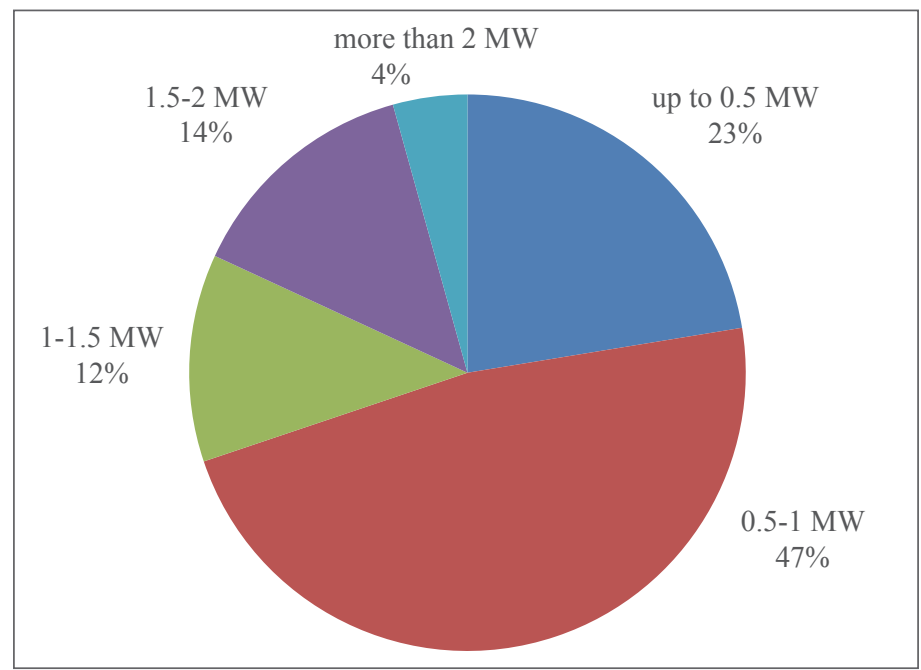

Fig. 3. Structure of the installed electric capacity of agricultural biogas plants in Poland in 2020. Source: own study based on the National Center..., 2020.

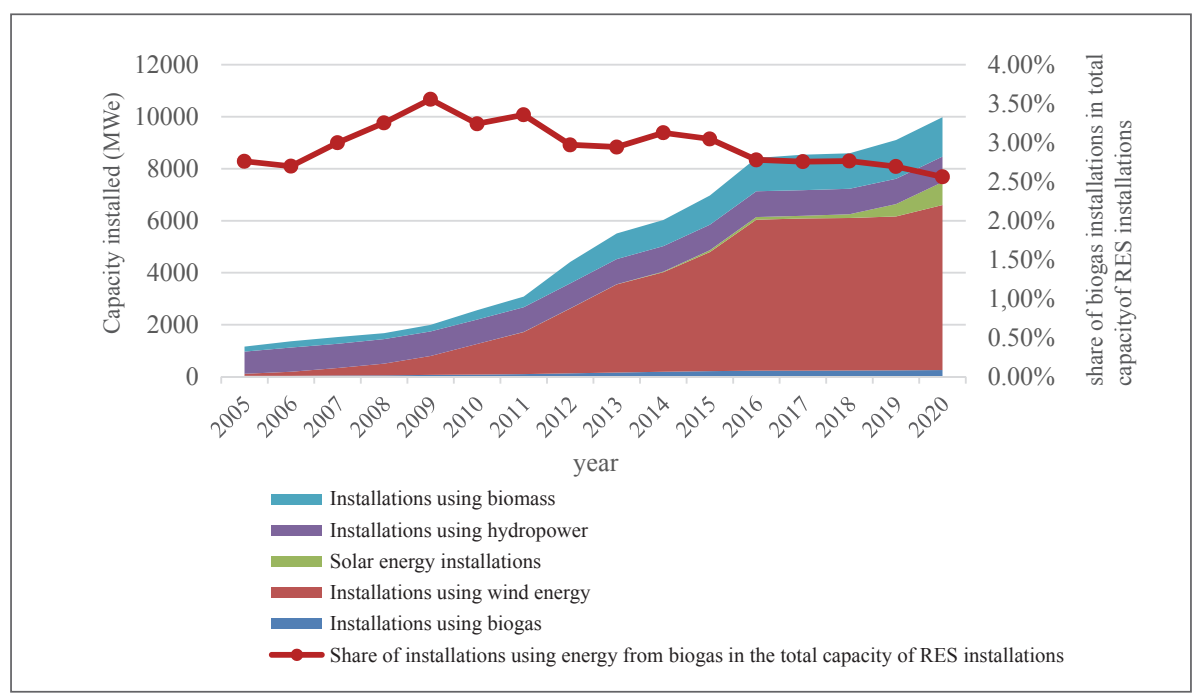

Fig. 4. Installed RES capacity in Poland from 2005-2020 (MWe).

Source: Energy Regulatory Office.

The minor importance and slow development of the biogas sector (agricultural and non-agricultural) in Poland are also indicated by comparison with other types of RES. The data of the Energy Regulatory Office presented in Figure 4 shows that the total electric power installed in biogas plants constitutes only slightly more than $2.5 \%$ of the total power of devices generating energy from renewable sources. 
A clear downward trend has also been observed in the share of installations using biogas for more than 10 years. The structure of the installed RES capacities is dominated by installations using wind energy, even though there has also been stagnation in this RES category since 2015. In general, the fastest rate of increase in RES capacity occurred between 2010 and 2015, followed by a marked slowdown in the development of most sources, except for photovoltaic installations.

\section{Technological aspects}

Since agricultural biogas plants in Poland began to be established only after 2005, the dominant biogas production technologies in Polish installations are based on foreign solutions - most often German and Austrian (Curkowski et al., 2011). Currently, most biogas plants in Poland and Europe are based on the NaWaRo technology ${ }^{1}$ or related solutions (Pochwatka and Pulka, 2020). All phases of methane fermentation in them take place in one fermentation chamber (Marks et al., 2020).

In the first years of market development, agricultural biogas plants were most often constructed in the immediate vicinity of large pig farms or large-scale farms (Curkowski et al., 2011). It was determined by the possibility of obtaining a large amount of raw materials such as slurry and maize silage, the basis for the NaWaRo technology (Marszałek, Banach, and Kowalski, 2011). In recent years, there has been a change in the biogas production model from the typical for Germany (where a large amount of raw materials of agricultural origin is used, grown on purpose) to the so-called Danish model, in which the biogas plant mainly acts as a bio-waste utilizer (Gostomczyk, 2017). It can be observed that the share of waste substrates is increasing, including fruit and vegetable residues, expired food, waste from the agrifood and dairy industry or slaughterhouse waste, and at the same time the share of maize and slurry is decreasing (Fig. 5). This process should be assessed positively, because feeding biogas plants with plants intentionally grown for biogas substrates (first generation) $)^{2}$ is controversial due to competition for food and fodder crops (Majewski et al., 2016) and increasing the risk of monocultures (Marks and in., 2020). At the same time, replacing expensive maize silage with cheaper waste substrates helps to improve the economic results of biogas plants (Gostomczyk, 2017).

\footnotetext{
${ }^{1}$ In the literature on the subject, the term "NaWaRo type biogas plant" is quite commonly used. It refers to the German market-specific biogas production technology, the prototype is a solution developed by BioEnergie AG, the subject of the NAWARO ${ }^{\circledR}$ patent.

${ }^{2}$ For example, to supply an agricultural biogas plant with a capacity of $1 \mathrm{MW}$ with maize silage, it is necessary to allocate up to 400 ha of agricultural land for cultivation (Ginalski, 2011).
} 


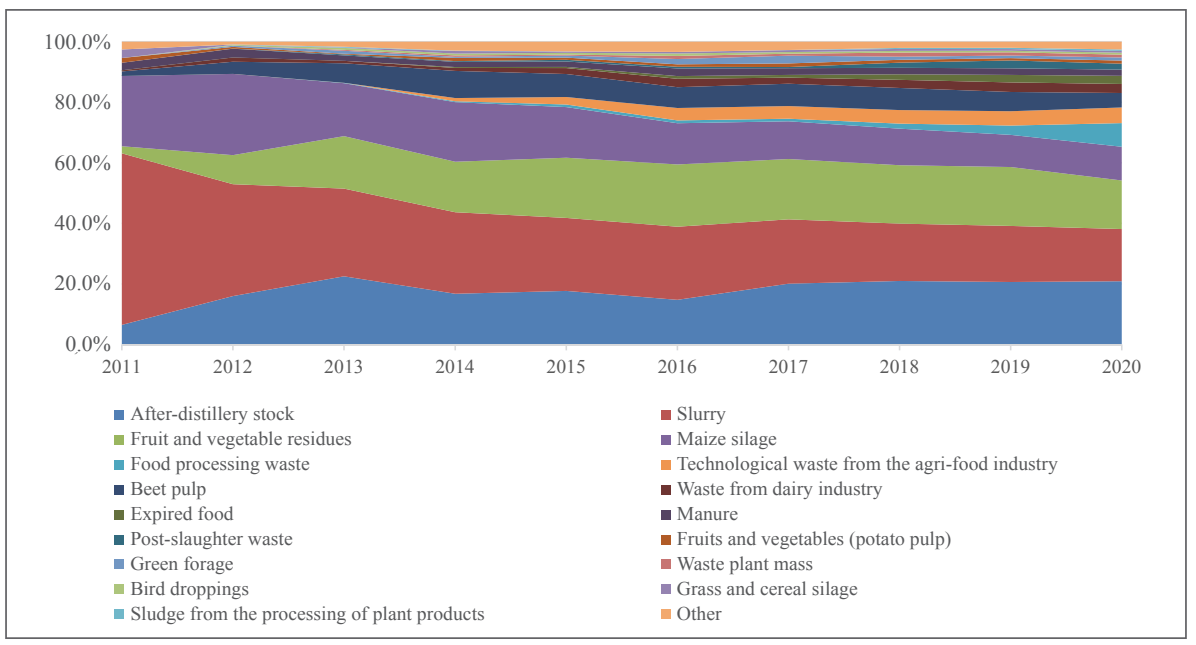

Fig. 5. Structure of substrates used in agricultural biogas plants in Poland from 2011-2020. Source: own study based on the National Center..., 2020

It is worth noting that in addition to changes in the structure of substrates, in the last few years there has also been an improvement in the efficiency of electricity production from agricultural biogas. In 2014, $1 \mathrm{MW}$ of the installed capacity of agricultural biogas plants produced an average of 5,230 MWh per year (which is about $59 \%$ of the theoretical level of $8,760 \mathrm{MWh}$ ), while in 2020 it was 5,825 MWh (which was about $66 \%$ of the theoretical level and meant an increase by $11 \%$ ). The recently observed improvement in the efficiency of agricultural biogas plants in Poland may be related to, inter alia, the so-called learning effect (Wiesenthal et al., 2012) and a better mastery of the complex production technology by producers and the development of the domestic technological base (Igliński et al., 2020).

\section{Evolution of forms of financial support and their significance for the economy of the industry}

Due to the high investment and operational costs of production installations, the production of renewable energy from biogas is the most expensive option among all RES types; depending on the adopted production and financial assumptions, the cost of $1 \mathrm{kWhe}$ calculated using the LCOE method ranges from 10.14 to 14.74 eurocents (Fraunhofer Institute, 2018). Thus, the state support system for renewable energy sources in force in the country is the main determinant of the development of the biogas sector (Majewski et al., 2016, Sulewski et al., 2016, Wąs et al., 2019).

The first model of public support in force in Poland was the system of certificates of origin ("color certificates") introduced by amendments to the Energy Law and Environmental Protection Law in 2004. It was a consequence of Poland's accession to the European Union (Directive 2001/77/EC). The system is based on the principle of purchase and redemption of certificates by energy companies selling energy to end users. 
The need for energy enterprises to purchase certificates of energy origin results from the obligation imposed on them to demonstrate a specific share of energy from RES in the production structure. To meet this requirement, the enterprises purchase a certain number of certificates of origin corresponding to the volume of electricity generated in RES installations. Alternatively, the companies can pay the so-called substitute fee. Thanks to this solution, energy companies do not have to launch their own installations to demonstrate that a specific share of RES in their production has been achieved.

Since the introduction of the certification system in 2005, biogas plants had the right to apply for a "green" (basic) certificate and in most cases for high-efficiency cogeneration ("yellow" or "purple") certificates. Between 2005 and 2010, the prices of "green certificates" were at the level of the substitution fee (about PLN 250), because of an insufficient number of RES installations in relation to the level of the certificate redemption obligation. According to the report of the Polish Chamber of Commerce for Renewable and Distributed Energy from 2018 (PIGEOR, 2018), in 2005-2010 the shortage of certificates on the market amounted to approx. 5.4 TWh. The RES obligation was performed with a surplus through substitution fees (in this period, the fees could be compared to as much as $7.3 \mathrm{TWh}$ ). Such behavior of entities obliged to achieve the RES target resulted in the creation of a real surplus of certificates on the market, even though the annual production of renewable energy in this period was lower than the annual volume of certificates required to be redeemed. A significant increase in the volume of renewable energy produced, combined with the real surplus of certificates between 2005 and 2010, amounting to approx. $2 \mathrm{TWh}$, decisively influenced the decline in their prices.

Between 2005 and 2016, a practically continuous mismatch between supply and demand could be observed on the market of green certificates. After the initial shortage of green certificates between 2005 and 2010, an excess of green certificates has been observed since 2011 due to excess production of energy from renewable sources in relation to the legislative requirements (ordinance of the minister responsible for energy on the detailed scope of obligations to obtain and submit certificates of origin for redemption from 2005, 2006, 2008, 2012, 2016). The fact, together with the unjustified payment of the substitution fee by energy companies in previous years and the excessive increase in the co-combustion of biomass ${ }^{3}$ (PIGEOR, 2018), contributed to the creation of a significant accumulated surplus of unredeemed certificates (23 TWh at the end of 2017). It resulted in a radical drop in prices (Fig. 6), resulting in a significant reduction in revenues from each MWh of produced energy. While the unit revenue in 2011 can be estimated at PLN 588.36/MWh, in the first half of 2016 it was only PLN 351.90 (a decrease by 40\%).

\footnotetext{
${ }^{3}$ The authors of the study indicate that the rapid increase in biomass prices caused by the significant demand for the raw material inhibited the development of the market of installations adapted only to biomass combustion.
} 
This was due to the collapse in prices of "green certificates", as well as the withdrawal (from the beginning of 2013 to July 2014) of support for the sale of "yellow" cogeneration certificates (PMGM instrument on TGE) worth approximately PLN 120 per MWh. During the period, biogas producers could additionally receive only revenues from the sale of the so-called "purple certificates". The price of them fluctuated around the substitution fee of about PLN 60 per $1 \mathrm{MWh}$.

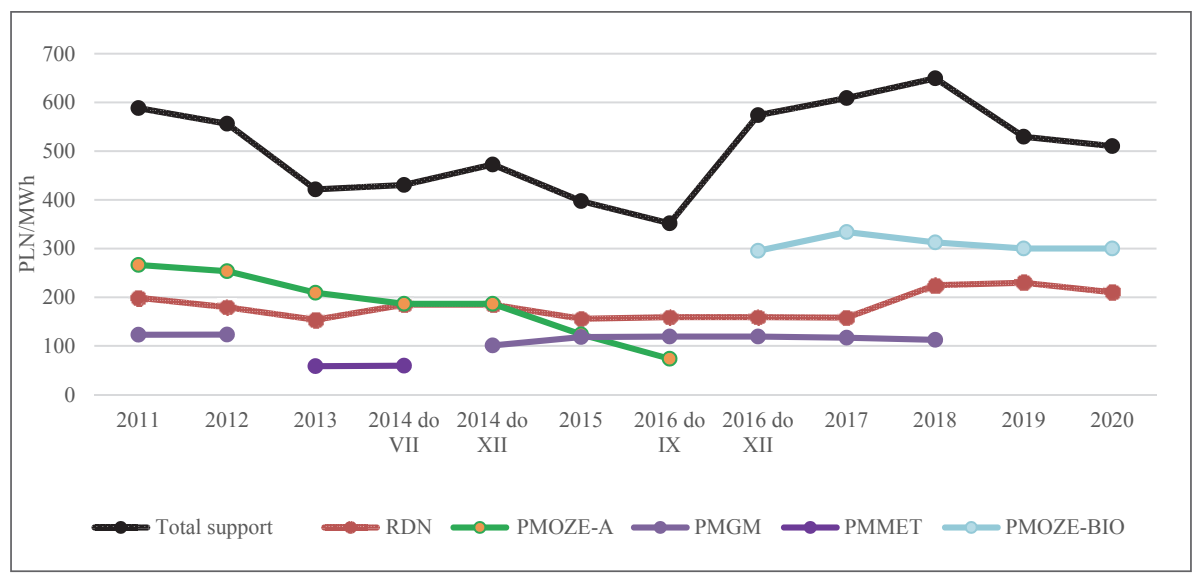

Fig. 6. Annual weighted average prices of electricity and certificates of origin from 2011-2020*.

* DAM - TGE Day-Ahead Market, PMOZE-A - green certificate, PMGM - yellow certificate, PMMET purple certificate, PMOZE-BIO - blue certificate.

Source: stock exchange reports of Towarowa Giełda Energii (TGE) from 2011-2020 (tge.pl); annual reports of RWE (later Innogy) "The Electricity and Gas Market in Poland" (innogy.pl); annual reports of the Association of Energy Trading (TOE) (toe.pl); annual reports of the TAURON Polska Energia S.A. Capital Group (tauron.pl).

The financial situation improved only after the entry into force of the Act on renewable energy sources in 2016 (Journal of Laws of 2015, item 478, as amended) and the introduction of certificates of origin dedicated exclusively to energy from agricultural biogas (the so-called "blue certificate"). The price quotations of "blue" certificates remained relatively stable throughout the entire period of operation (at the level of the substitution fee of PLN 300.03).

The 2016 amendment to the RES Act also introduced a new support system - renewable energy auctions organized by the Energy Regulatory Office. Both existing installations and those launched after July 1, 2016, could join them, but new installations could no longer benefit from the support in the form of certificates. To ensure appropriate conditions for fair competition, a division into "baskets" was introduced. Entrepreneurs operating installations with similar technological solutions could compete in them (this limited the problem of competition between technological solutions of different labor and cost intensity). A division of auctions was also introduced according to sizes of installations (with a capacity greater and lower than $1 \mathrm{MW}$ ). The auction system also included the so-called reference price, i.e., the maximum 
price for which electricity could be sold (in 2016 it was PLN 550/MWh). The price of the winning auction was also subject to annual indexation by the consumer price index, and the support period was foreseen for a maximum of 15 years.

The first RES auction on December 30, 2016, did not arouse much interest among producers of electricity from agricultural biogas (a total of 7 installations received support). In turn, in 2017, no biogas installation entered the auction system. The main factors contributing to the low interest in auctions among the owners of agricultural biogas plants include the expected contractual penalties, e.g., for producing less than $85 \%$ of the declared energy, and the need for settling public aid received at the investment stage.

Another significant amendment to the RES Act of 2018 (Journal of Laws 2018, item 1276) brought about further changes significant from the perspective of agricultural biogas plants. The most important of them concerned the introduction of a feed-in tariff system. It could be joined by agricultural biogas plants with an installed capacity of no more than $1 \mathrm{MW}$. The tariff system is in principle like the auction system, but in some respects, it seems to be more favorable to producers. Firstly, a failure to produce the declared amount of energy during a year does not constitute grounds for penalizing the producer.

The expiry of the obligation to redeem co-generation certificates at the end of 2018 was another important aspect in the context of the support systems for agricultural biogas plants in Poland, and the new support system for electricity generation in cogeneration was effective as of January 25, 2019. At the end of August 2019, another amendment to the RES Act entered into force. It introduced several changes correcting some of the previous provisions. On April 13, 2021, the Council of Ministers adopted a draft amendment to the RES Act presented by the Ministry of Climate and Environment (UDT-107). It assumed, inter alia, the extension of the possibility to enter the auction system until 31 December 2021, and in the case of feed-in tariff systems until 30 June 2024. Several administrative facilitations were also introduced (e.g., increasing the capacity limit of an installation, for which it is not necessary to include the facility in the spatial development study of a commune - from 0.1 to $0.5 \mathrm{MW}$ ). Figure 7 summarizes the key events in the evolution of forms of agricultural biogas support.

The discussed legislative changes about the support system clearly differentiate the level of revenues obtained by biogas plants currently operating in Poland. Figure 8 shows the level of revenues from 1 MWh of electricity generated in 2020 depending on the form and method of support used by the given biogas plant. A biogas plant operating in the certificate system receives support for each megawatt hour of electricity produced, including the amount of energy used for the biogas plant's own needs (gross energy). In turn, in the auction and feed-in tariff systems, the support is settled based on net energy, i.e., the amount of energy fed into the power grid. Moreover, the revenue of a biogas plant operating in the system of certificates of origin, as opposed to auctions and tariffs, is largely dependent on the price quotations on the market (price risk). 


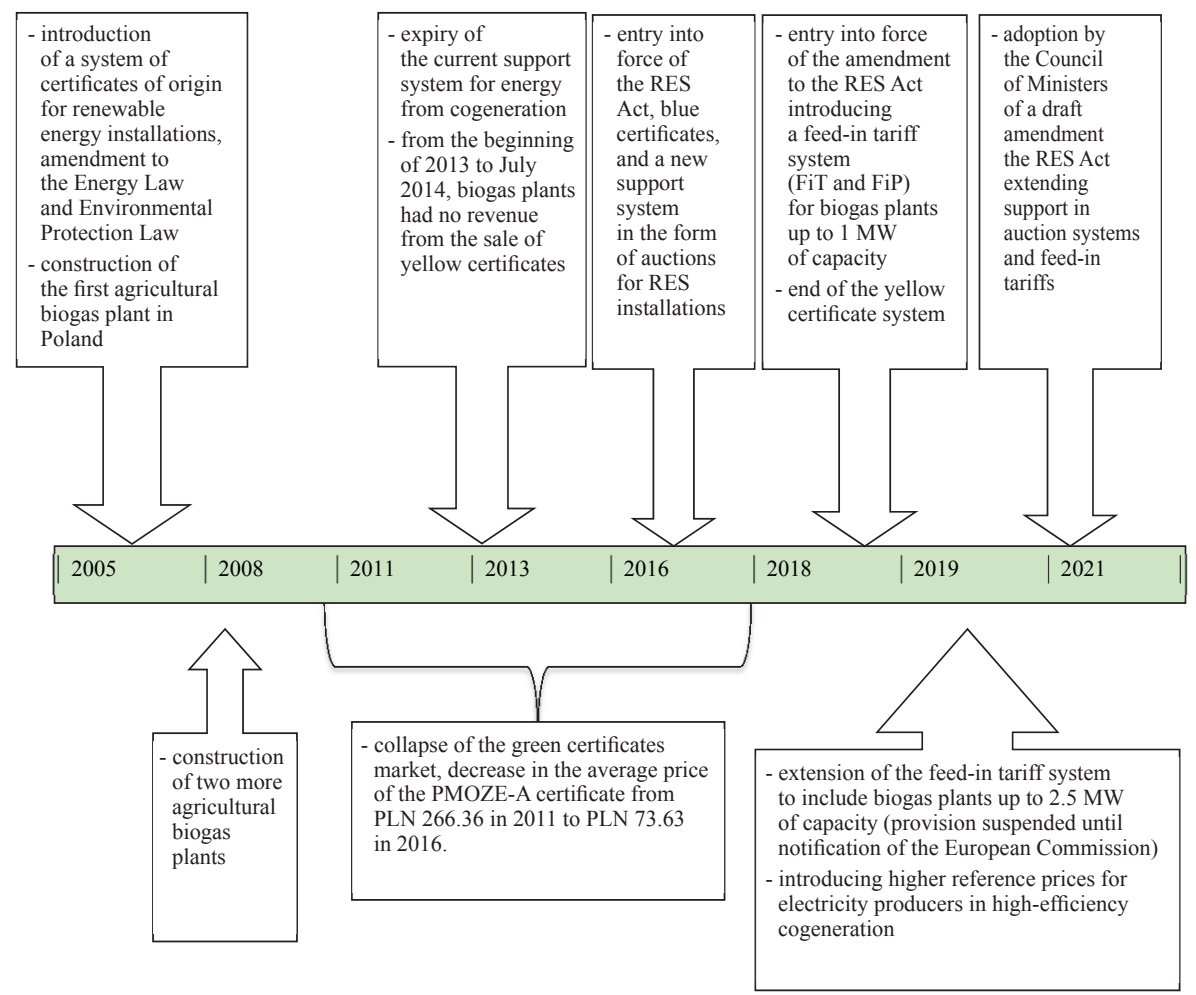

Fig. 7. Evolution of support forms for agricultural biogas producers in Poland and key events in the development of the industry.

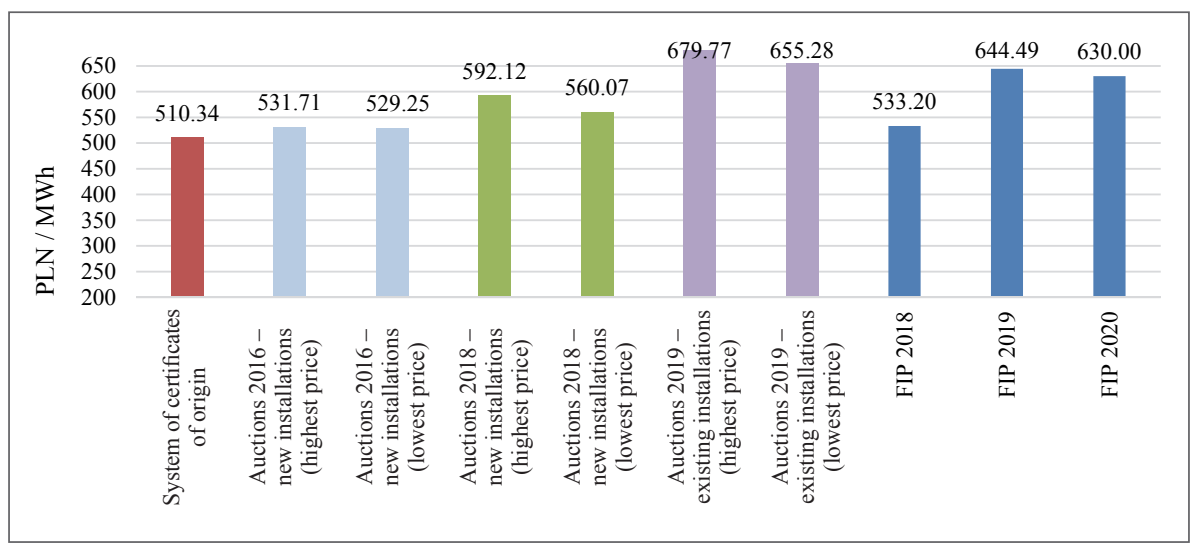

Fig. 8. Level of unit revenue (PLN/1 MWh of electricity) from the production of agricultural biogas in a $1 \mathrm{MW}$ installation depending on the variant of the support system used by the entrepreneur in 2020.

Source: own study based on data from the Energy Regulatory Office, TGE, and regulations of the minister responsible for energy. 
As shown in Figure 8, in 2020 the lowest unit revenue was achieved by a biogas plant operating in the system of certificates of origin - it was approx. PLN 510/MWh on average. A slightly higher revenue was recorded in installations that entered the auction system in 2016 (approx. PLN 530). The biogas plant that joined the feed-in tariff system introduced in 2018, could obtain a fixed revenue in the amount of approx. PLN 533/MWh in 2020. The biogas producers who won the auction in 2018 could obtain revenue by over $10 \%$ higher in 2020 . The installations that were included in the above-mentioned system in 2019 were in a much better financial situation. New reference prices were then introduced for electricity generated from agricultural biogas in cogeneration (along with the entry into force of the Act on the promotion of electricity from high-efficiency cogeneration). For example, in the case of feed-in tariffs, a biogas plant participating in this system from 2019 could obtain a unit price almost $25 \%$ higher than a producer who joined the system a year earlier.

\section{Conditions for further development of the agricultural biogas industry in Poland - an attempt at a synthesis using the S-C-P model}

Figure 9 presents a synthetic summary of the factors characterizing the agricultural biogas industry in Poland in the form of the S-C-P model (Structure-ConductPerformance). It is one of the methods of strategic analysis of the sector (industry) (Matyjas, 2014).

The application of the S-C-P approach enables the ordering of the factors determining the results of enterprises. It may constitute a starting point for determining the attractiveness of the industry and, consequently, the assessment of its development possibilities. The key element determining the operating conditions in the agricultural biogas industry is the state policy. It plays a fundamental role both in stimulating the demand for agricultural biogas and in shaping the supply. Due to high entry barriers related to the level of investment expenditure and low production profitability, the state support system for biogas producers directly translates into investment decisions of potential producers and the structure of the industry (the existing support systems differentiated the level of aid depending on the capacity of the installation). The expected energy transformation is a factor that will probably increasingly stimulate the increase in demand for energy from renewable sources (including biogas), but the strength of this impact will be shaped by detailed legal solutions (as results from historical experience). The dynamically growing energy prices in Poland should be considered an element stimulating the attractiveness of energy production from renewable energy sources, including agricultural biogas. It will reduce the differences in the profitability of production from conventional and renewable sources, increasing the relative attractiveness of renewable energy. The Directive of the European Parliament and the EU Council on the promotion of the use of energy from renewable energy sources (the so-called RED II) adopted in 2018 may also be the factor stimulating the development of the industry. One of its assumptions is to increase the share of renewable energy sources in transport (to $14 \%$ in 2030 , including $3.5 \%$ from second-generation biofuels). 
The regulations provide the possibility of double counting biogas and biofuels used for transport if they are produced from raw materials such as manure and waste from the agri-food industry. Signing a letter of intent to establish a partnership for the development of the biogas and biomethane sector and conclusion of a sectoral agreement between the Ministry of Climate and Environment and representatives of the biogas and transport industry are expressions of an increased interest in biogas in the transport sector (October 2020).

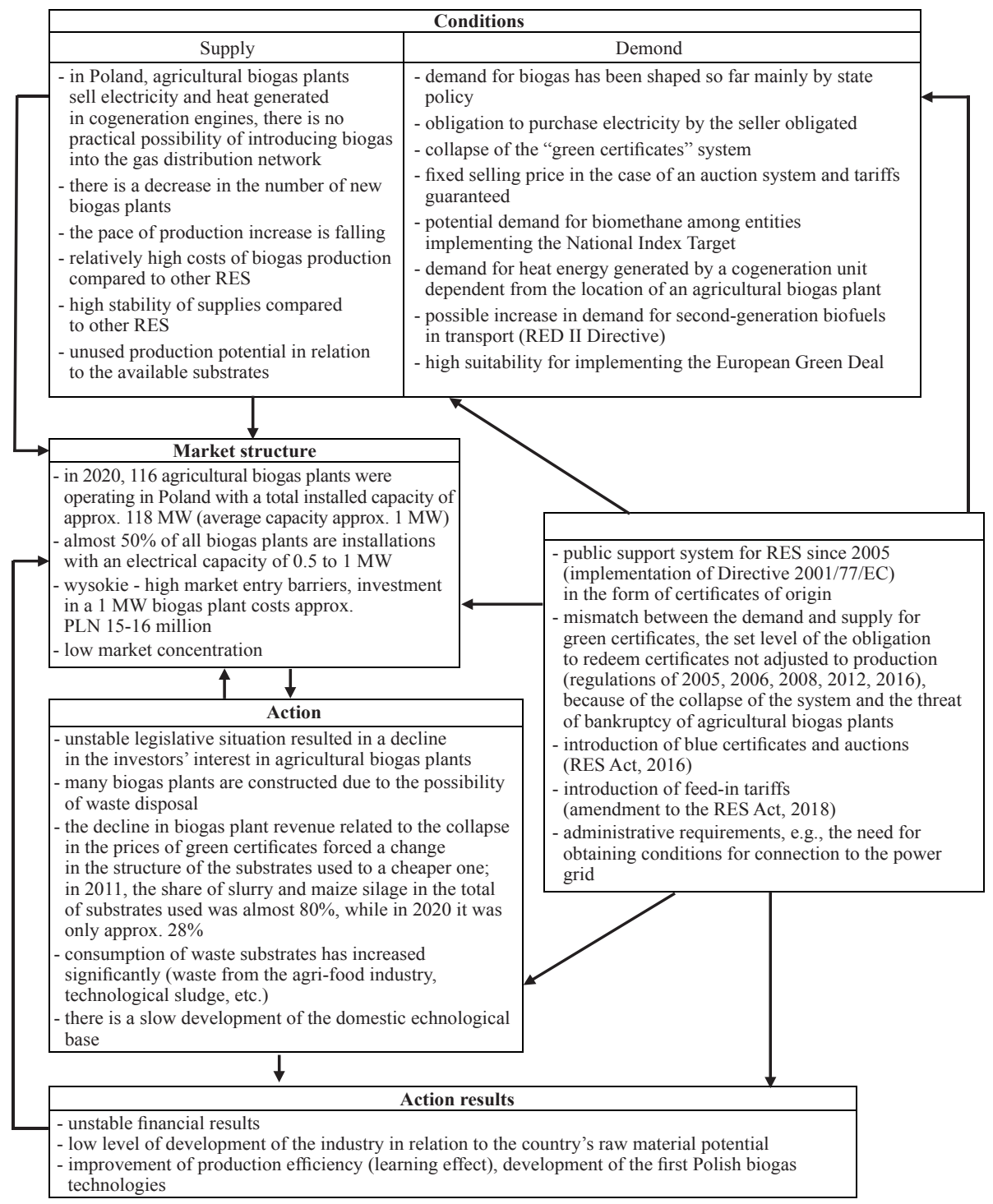

Fig. 9. S-C-P (Structure-Conduct-Performance) model for the agricultural biogas market from 2005-2020.

Source: own study. 


\section{Conclusions}

Due to high investment outlays and production costs, the pace of development of the agricultural biogas industry depends on decisions made by policymakers. Due to the unstable level and changing forms of public support as well as complicated formal and legal conditions, the development of the agricultural biogas industry in Poland has been practically halted in recent years (after a short period of relatively faster growth between 2010 and 2015). Considering the changes occurring in the political and legal environment, in particular the EU policy related to counteracting climate change (as reflected in the European Green Deal), a change in unfavorable conditions can be expected. Agricultural biogas has many features that justify the increase in its importance in energy production. They, in total, outweigh the weaknesses of this solution source. It is a more stable source than other RES categories, and by managing agricultural waste, it additionally reduces greenhouse gas emissions from agriculture. So far, agricultural biogas produced in Poland has been transformed into electricity and heat, but recently there has been an increased interest in alternative ways of using this raw material as a gaseous fuel, i.e., as bioCNG, bioLNG or as a bio-component to produce biohydrogen. It may expand the sales opportunities and improve the operational efficiency of agricultural biogas plants (so far, the problem was the use of heat energy, which reduced the efficiency of the facility). In conjunction with the planned simplification of formal requirements and extension of the period of operation of support systems, this creates an opportunity to increase the dynamics of creating new installations. It should be emphasized that maintaining financial support for agricultural biogas plants is also of key importance for technological reasons - an inhibition of market development at the current stage (resulting from under-financing) would translate into a slowdown in the technological progress of biogas installations. It can also be expected that increased attractiveness of agricultural biogas (similarly to other renewable energy sources) in the coming years will be influenced by the growing prices of energy obtained from fossil sources (which is determined, among others, by the growing costs of $\mathrm{CO}_{2}$ emission allowances). Currently, however, the potential of biogas production resulting from the availability of substrates is used to a small extent. In this context, it is also necessary to signal the need for introducing systemic solutions aimed at limiting the problem of the scale of investments, e.g., by subsidizing group investments (especially due to the large fragmentation of the area structure of farms in Poland). The story of the agricultural biogas industry in Poland to date (relatively short as it began in 2005) indicates that the awareness of the benefits of agricultural biogas production among political decision-makers was probably relatively low. It translated into administrative barriers and volatile economic conditions. In this context, it seems justified to disseminate knowledge about the environmental and economic benefits that the development of the agricultural biogas industry may bring. It is particularly important in the context of the assumptions of the European Green Deal. 


\section{References}

Act of 10 April 1997 on Energy Law (Ustawa z dnia 10 kwietnia 1997 r. - Prawo energetyczne. Dz.U. 1997, nr 54, poz. 348, z późn. zm.)

Act of 20 February 2015 on renewable energy sources (Ustawa z dnia 20 lutego 2015 r. o odnawialnych źródłach energii. Dz.U. 2015, poz. 478 z późn. zm.)

Act of 7 June 2018 amending the Act on renewable energy sources and certain other acts (Ustawa z dnia 7 czerwca 2018 r. o zmianie ustawy o odnawialnych źródłach energii oraz niektórych innych ustaw. Dz.U. 2018 poz. 1276.)

Act of 14 December 2018 on the promotion of electricity from high-efficiency cogeneration (Ustawa z dnia 14 grudnia 2018 r. o promowaniu energii elektrycznej z wysokosprawnej kogeneracji. Dz.U. 2019, poz. 42, z późn. zm.)

Besi, de M., McCormick, K. (2015). Towards a Bioeconomy in Europe: National, Regional and Industrial Strategies. Sustainability, 7(8), pp. 10461-10478.

Birner R. (2018). Bioeconomy Concepts. In: I. Lewandowski (ed.), Bioeconomy: Shaping the Transition to a Sustainable, Biobased Economy. Springer OPEN, University of Hohenheim.

Boulding, K.E. (1966). The Economics of the Coming Spaceship Earth. W: Environmental Quality in a Growing Economy. Baltimore: Johns Hopkins University Press.

BÖR (BioÖkonomieRat) (2010). Bio-Economy Council Report 2010. Bio-Economy Innovation.

Bruins, E.M., Sanders, J.P.M. (2012). Small-Scale Processing of Biomass for Biorefinery. Biofuels, Bioproducts and Biorefining, 6(2), pp. 115-232.

Curkowski, A., Oniszk-Popławska, A., Mroczkowski, P., Zowsik, M., Wiśniewski, G. (2011). Przewodnik dla inwestorów zainteresowanych budową biogazowni rolniczych. Warszawa: Ministerstwo Gospodarki, Instytut Energetyki Odnawialnej.

Dabbert, S., Lewandowski, I., Weiss, J., Pyka, A. (2017). Knowledge - Driven Developments in the Bioeconomy. Technological and Economic Perspectives. Springer International Publishing.

Dach, J., Janczak, W., Czekała, W. (2018). Potencjał biogazowy w Polsce - aktualne dane. Magazyn Biomasa, 9(49), pp. 40-43.

Dach, J., Matyka, M.,Białowiec, A., Kowalczyk-Juśko, A., Pituła, M., Sługocki, Z. (2020). Raport Biogaz w Polsce. Biomass Media Group Sp. z o.o.

Directive of the European Parliament and the EU Council 2018/2001 of 11 December 2018 on the promotion of the use of energy from renewable energy sources.

Dobbelaere De, A., Keulenaere De, B., Mey De, J., Lebuf, V., Meers, E.,.Ryckaert, B., Schollier, C., Driessche, van D. (2015). Small-Scale Anaerobic Digestion. Case Studies in Western Europe.

Ellen MacArthur Foundation (2013). Towards the Circular Economy: Economic and Business Rationale for an Accelerated Transition. Cowes, UK: Ellen MacArthur Foundation Rethink the Future.

Energy Regulatory Office. Potencjał krajowy OZE w liczbach. Retrieved from: https:/www.ure. gov.pl/pl/oze/potencjal-krajowy-oze (access date: 11.05.2021).

European Commission (2012). Innovating for Sustainable Growth. A Bioeconomy For Europe. Brussels: European Commission.

European Commission (2019a). Komunikat Komisji do Parlamentu Europejskiego, Rady Europejskiej, Rady, Komitetu Ekonomiczno-Społecznego i Komitetu Regionów. Europejski Zielony Ład. COM/2019/640.

European Commission (2019b). Czysta energia dla wszystkich Europejczyków. Luksemburg: Urząd Publikacji Unii Europejskiej. 
European Environment Agency (2020). Annual European Union Greenhouse Gas Inventory 1990-2018 and Inventory Report 2020. Submission to the UNFCCC Secretariat. Brussels: European Commission, DG Climate Action.

European Parliament (2012). Institutional framework for sustainable development in the context of the forthcoming Rio+20 Summit. Directorate-General for Internal Policies. Policy Department Economic and Scientific Policy - Brussels, European Parliament. Eurostat (2021). Share of Energy From Renewable Sources. Retrieved from: https://ec.europa.eu/ eurostat/databrowser/view/nrg_ind_ren/default/table?lang=en (access date: 10.05.2021).

Filho, W.L., Pociovălișteanu, D.M., Brito de, P.R.B., Lima de I.B. (2018). Towards a Sustainable Bioeconomy: Principles, Challenges and Perspectives. Springer International Publishing AG. Nowy Jork: Springer International Publishing AG.

Fraunhofer Institute for Solar Energy Systems (2018). Levelized Cost of Electricity-Renewable Energy Technologies. Freiburg: Fraunhofer ISE.

Fritsche, U., Brunori, G., Chiaramonti, D., Galanakis, C., Hellweg, S., Matthews, R. Panoutsou, C. (2020). Future Transitions for the Bioeconomy towards Sustainable Development and a Climate-Neutral Economy-Knowledge Synthesis Final Report. Luxembourg: Publications Office of the European Union.

Ginalski, Z. (2011). Substraty dla biogazowni rolniczych. Radom: Centrum Doradztwa Rolniczego.

Gołębiewski, J. (2019). Systemy żywnościowe w warunkach gospodarki cyrkularnej studium porównawcze krajów Unii Europejskiej. Warszawa: Wydawnictwo SGGW.

Gołębiewski J. (2013). Zrównoważona biogospodarka - potencjat i czynniki rozwoju. Conference materials, IX Kongres Ekonomistów Polskich 2013.

Gołębiowski, K., Holewa-Rataj, J., Koch-Kopyszko, S., Kukulska-Zając, E., Krysiuk, I., Rogowska, D., Rogulska, M., Samson-Bręk, I., Siuda, A., Stępień, A., Zawisza, A. (2021). Biała Księga Biometanu. Bariery rozwoju sektora biometanu w Polsce oraz proponowane rozwiazania. Warszawa: Koalicja na Rzecz Biometanu.

Gostomczyk, W. (2017). Stan i perspektywy rozwoju rynku biogazu w UE i Polsce - ujęcie ekonomiczne. Zeszyty Naukowe SGGW w Warszawie - Problemy Rolnictwa Światowego, 17(32), pp. 48-64.

Gradziuk, P. (2015). Gospodarcze znaczenie i możliwości wykorzystania słomy na cele energetyczne w Polsce. Monografie i Rozprawy Naukowe, No. 45. Puławy: IUNG-PIB.

Hakawati, R.,Smyth, B.,Mccullough, G., Rosa, F., Rooney, D. (2017). What is the Most Energy Efficient Route for Biogas Utilization: Heat, Electricity or Transport? Applied Energy, 206, 1076-1087.

Igliński, B., Piechota, G., Iwański, P., Skarzatek, M., Pilarski, G. (2020). 15 Years of the Polish Agricultural Biogas Plants: Their History, Current Status, Biogas Potential and Perspectives. Clean Technologies and Environmental Policy, 22(2), pp. 281-307.

Intergovernmental Panel on Climate Change (IPCC) (2006). Guidelines For National Greenhouse Gas Inventories. Vol. 4 Agriculture, Forestrand Other Land Use.

Kisiel, R. (2006). Biomasa pozyskiwana z gruntów rolniczych źródłem energii. Zagadnienia Ekonomiki Rolnej, No. 4(309), pp. 90-101.

Kowalczyk-Juśko, A., Szymańska, M. (2015). Poferment nawozem dla rolnictwa. Warszawa: Fundacja na rzecz Rozwoju Polskiego Rolnictwa.

National Center for Agricultural Support (2020). Dane dotyczące działalności wytwórców biogazu rolniczego w latach 2011-2020. Retrieved from: https://bip.kowr.gov.pl/informacje-publiczne/ odnawialne-zrodla-energii/biogaz-rolniczy/dane-dotyczace-dzialalnosci-wytwo-rcowbiogazu-rolniczego-w-latach-2011-2020 (access date: 12.05.2021). 
Maciejczak, M. (2017). Bioeconomy as a Complex Adaptive System of Sustainable Development. Journal of International Business Research and Marketing, 2(2), pp. 7-10.

Majewski E., Sulewski P., Wąs,, A. (2016). Potencjat produkcji biogazu rolniczego w Polsce. Warszawa: Wydawnictwo SGGW.

Marks, S., Dach, J., Fernandez Morales, F. J., Mazurkiewicz, J., Pochwatka, P., Gierz, Ł. (2020). New Trends in Substrates and Biogas Systems in Poland. Journal of Ecological Engineering, 21(4), pp. 19-25. DOI: https://doi.org/10.12911/22998993/119528.

Marszałek, M., Banach, M., Kowalski, Z. (2011). Utylizacja gnojowicy na drodze fermentacji metanowej i tlenowej - produkcja biogazu i kompostu. Czasopismo Techniczne. Chemia, 108(2-Ch), pp. 143-158.

Matyjas, Z. (2014). The Role of the Structure-Conduct-Performance Paradigm for the Development of Industrial Organization Economics and Strategic Management. Journal of Positive Management, 5, pp. 53-63.

Ministry of Climate (2020). Poland's National Inventory Report 2020. Greenhouse Gas Inventory For 1988-2018. Submission under the United Nations Framework Convention on Climate Change and the Kyoto Protocol. Warszawa: KOBiZE, IOŚ-PIB.

Mirosz, L., Amrozy, M., Trzaski, A., Wiszniewska A. (2015). What Policymakers Should Know About Micro-Scale Digestion. BioEnergy Farm II - Manure, the Sustainable Fuel For the Farm. Intelligent Energy Europe Programme of the European Union. Warszawa: National Energy Conservation Agency (NAPE).

O'Brien, C. (1999). Sustainable Production - A New Paradigm for a New Millennium. International Journal of Production Economics, 60(1), pp. 1-7.

Obrycka, E. (2014). Korzyści społeczne i ekonomiczne budowy biogazowni rolniczych. Zeszyty Naukowe SGGW w Warszawie - Ekonomika i Organizacja Gospodarki Żywnościowej (107), pp. 163-176.

Organisation for Economic Cooperation and Development (OECD) (2009). The Bioeconomy to 2030: Designing a Policy Agenda. Main Findings. Paryż: OECD.

Paterson, M., Amrozy, M., Berruto, R., Bijnagte, J.W., Bonhomme, S., Gysen, M., Kayser, K., Majewski, E., Parola, F. (2016). Implementation Guide For Small-Scale Biogas Plants. BioEnergy Farm II Publication, Vol. 1.2, Kuratorium für Technik und Bauwesen in der Landwirtschaft e.V. (KTBL). Darmstadt: KTBL.

Pawlak, J. (2013). Biogaz z rolnictwa korzyści i bariery. Problemy Inżynierii Rolniczej, 21(3), pp. 99-108.

Pedroli, B., Langeveld, H. (2011). Impacts of Renewable Energy on European Farmers. Final Report for the European Commission Directorate-General Agriculture and Rural Development. Alterra Wageningen UR, Ecologic Institute, EC BREC IEO, SORIACTIVA, ECN, Wageningen University.

Pochwatka, P., Pulka, J. (2020). Biogaz rolniczy - nowe otwarcie. Trzoda Chlewna, 9, pp. 72-74.

Polska Izba Gospodarcza Energetyki Odnawialnej i Rozproszonej (2018). Obiektywne i subiektywne przyczyny destrukcji systemu zielonych certyfikatów w latach 2005-2016. Warszawa: PIGEOR.

Pomykała, R., Łyko, P. (2013). Biogaz z odpadów (bio)paliwem dla transportu - bariery i perspektywy. Chemik, 67(5), pp. 454-161.

Pyka, A., Prettner, K. (2018). Economic Growth, Development and Innovation: The Transformation Towards a Knowledge-Based Bioeconomy. In: I. Lewandowski (ed.): Bioeconomy. Shaping the Transition to a Sustainable Biobased Economy (pp. 329-340). Springer Open. University of Hohenheim. DOI:10.1007/978-3-319-68152-8_11. 
Ratajczak E. (2013). Rolnictwo i leśnictwo w świetle koncepcji biogospodarki. Warszawa: Materiały konferencyjne - IX Kongres Ekonomistów Polskich. Retrieved from: http://www. pte.pl/kongres/referaty/ (access date: 01.05.2021).

Rockström, J., Steffen, W., Noone, K. (2009). A Safe Operating Space for Humanity. Nature, 461, pp. 472-475.

Saavedra, Y.M.B., Iritani, D.R., Pavan, A.L.R., Ometto, A.R. (2018). Theoretical Contribution of Industrial Ecology to Circular Economy. Journal of Cleaner Production, 170, pp. 1514-1522.

Satterthwaite, D. (2006). Barbara Ward and the Origins of Sustainable Development. London: International Institute for Environment and Development.

Savini, F. (2019). The Economy that Runs on Waste: Accumulation in the Circular City. Journal of Environmental Policy \& Planning, 21(6), pp. 675-691.

Shih, J.S., Burtraw, D., Palmer, K., Siikamäki, J. (2012). Air Emissions of Ammonia and Methane from Livestock Operations: Valuation and Policy Options. Journal of the Air \& Waste Management Association, 58, pp. 1117-1129.

Sillanpaa, M., Ncibi, C. (2017). A Sustainable Bioeconomy. The Green Industrial Revolution. Springer International Publishing AG. Nowy Jork: Springer International Publishing AG.

Statistics Poland. System Wspomagania Analizi Decyzji. Bilanse nośników energii. Retrieved from: http://swaid.stat.gov.pl/GospodarkaPaliwowoEnergetyczna_dashboards/Raporty_predefiniowane/RAP_DBD_GPE_1.aspx (access date: 11.05.2021).

Stejskal, B. (2008). Praktyczne doświadczenia z prowadzenia biogazowni. Infrastruktura i Ekologia Terenów Wiejskich, 9, pp. 125-135.

Sulewski, P., Majewski, E., Wąs, A. (2017). Miejsce i rola rolnictwa w produkcji energii odnawialnej w Polsce i UE. Zagadnienia Ekonomiki Rolnej/Problems of Agriculture Economics, No. 1(350), pp. 50-74. DOI:10.5604/00441600.1234428.

Sulewski,P., Majewski,E., Wąs, A., Szymańska, M., Malak-Rawlikowska,A., Fraj,A., Trząski, A., Wiszniewski,A.,Amrozy, M.(2016). Uwarunkowania ekonomiczno-prawne i opłacalność inwestycjiwbiogazownierolniczewPolsce. ZagadnieniaEkonomikiRolnej, No. 1(346),pp. 119-143. DOI: $10.5604 / 00441600.1196369$.

System Wspomagania Analiz i Decyzji. Bilanse nośników energii. Retrieved from: http://swaid. stat.gov.p1/GospodarkaPaliwowoEnergetyczna_dashboards/Raporty_predefiniowane/ RAP_DBD_GPE_1.aspx. (access date: 11.05.2021).

Tarka, M., Trupkiewicz, M. (2017). Obowiązek dostępu do gazowej sieci dystrybucyjnej jako podstawowy warunek sprzedaży biometanu z polskich biogazowni rolniczych. Rynek Energii, 5, pp. 49-53.

United Nations Environment Programme (UNEP). (2011). Decoupling Natural Resource Use and Environmental Impacts From Economic Growth. A Report of the Working Group on Decoupling To the International Resource Panel. United Nations Environment Programme. Retrieved from: https://wedocs.unep.org/20.500.11822/9816 (access date: 10.05.2021).

Wąs, A., Sulewski, P., Szymańska, M. (2019). Biorafinerie rolnicze jako element trwałej biogospodarki. Warszawa: Wydawnictwo SGGW.

Wiesenthal, T., Dowling, P., Morbee, J., Thiel, C., Schade, B., Russ, P., Simões, S., Peteves, E., Schoots, K., Londo, M. (2012). Technology Learning Curves for Energy Policy Support. European Commission Joint Research Centre Institute for Prospective Technological Studies Institute for Energy and Transport. Luksemburg: Publications Office of the European Union. European Union. 
Wiśniewski, G., Więcka, A., Dziamski, P., Kamińska, M., Rosołek, K., Santorska, A. (2012). Małoskalowe odnawialne źródła energii i mikroinstalacje. Warszawa: Biuro Regionalne Europa Centralna.

World Bank (2018). What a Waste 2.0 : A Global Snapshot of Solid Waste Management to 2050. Washington D.C.: World Bank Group.

Woźniakowski, P. (2020). Biogaz w polityce Europejskiego Zielonego Ładu. Raport Biogaz w Polsce. Biomass Media Group Sp. z o.o. Poznań: Biomass Media Group Sp. z o.o.

Internet sources:

innogy.pl.

tauron.pl.

tge.pl.

toe.pl. 


\title{
UWARUNKOWANIA ROZWOJU SEKTORA \\ BIOGAZU ROLNICZEGO W POLSCE \\ W KONTEKŚCIE DOŚWIADCZEŃ HISTORYCZNYCH \\ I WYZWAŃ EUROPEJSKIEGO ZIELONEGO ŁADU
}

\begin{abstract}
Abstrakt
Celem opracowania była ocena dotychczasowego rozwoju branży biogazu rolniczego $w$ Polsce oraz wskazanie kluczowych czynników determinujacych możliwości upowszechniania tej kategorii energii odnawialnej w najbliższych latach. Artykut bazuje na danych wtórnych. Wopracowaniu wykorzystano dane statystyczne dotyczace produkcji biogazu rolniczego pochodzace ze statystyk Eurostatu, Urzędu Regulacji Energetyki oraz Krajowego Ośrodka Wsparcia Rolnictwa. Do syntetycznego przedstawienia zebranego materiatu i oceny sytuacji polskiej branży biogazu rolniczego zastosowano analize S-C-P (StructureConduct-Performance). Funkcjonujace w Polsce biogazownie rolnicze wytworzyty w 2020 roku jedynie około $325 \mathrm{mln}^{3}$ biogazu, z którego wyprodukowano 689 GWh energii elektrycznej. Stanowi to niewielka część potencjału biogazowego polskiego rolnictwa (różne opracowania wskazuja na potencjał $w$ zakresie 1,6-4,2 mld $\mathrm{m}^{3}$ biogazu rolniczego z nawozów organicznych powstajacych $w$ gospodarstwach rolnych). Energia elektryczna uzyskana z biogazu rolniczego pokrywa niespetna 0,4\% krajowego zapotrzebowania. Pomimo ambitnych planów sprzed kilkunastu lat rozwój branży biogazu rolniczego zastał praktycznie zahamowany. Główna tego przyczyna jest silne uzależnienie od systemu wsparcia środkami publicznymi. Dalszy rozwój branży biogazu wymaga stabilnego wsparcia finansowego. Pomimo negatywnych doświadczeń historycznych można oczekiwać, że w najbliższych latach rozwój branży przyspieszy. Wynika to z faktu, ze biogaz rolniczy posiada wiele zalet istotnych z punktu widzenia wyzwań Europejskiego Zielonego Ładu. Potrzebne jest jednak podnoszenie świadomości decydentów politycznych $w$ zakresie środowiskowych i ekonomicznych korzyści wynikających z upowszechniania produkcji biogazu rolniczego.
\end{abstract}

Słowa kluczowe: trwały rozwój, Europejski Zielony Ład, biogaz rolniczy, odnawialne źródła energii.

Submission date: 27.05.2021.

Final revision date: 16.06 .2021$.

Acceptance date: 21.07.2021.

Unless stated otherwise all the materials on the website are available under the Creative Commons Attribution 4.0 International license. Some rights reserved to the Institute of Agricultural and Food Economics - National Research Institute.

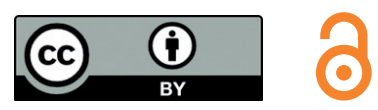

